\title{
MENINGKATKAN HASIL BELAJAR DENGAN MENGGUNAKAN PENDEKATAN SAINTIFIK PADA MATA PELAJARAN MATEMATIKA DI KELAS V SD NEGERI NO. 107402 SAENTIS
}

\author{
Demmu Karo-Karo \\ Surel: demmu_karokaro@yahoo.com
}

\begin{abstract}
ABSTRAK
Subjek penelitian adalah siswa kelas V SD Negeri No.107402 Saentis T.A 2015/2016 sebanyak 33 orang. Alat pengumpulan data yang digunakan adalah tes dan observasi untuk guru dan siswa. Pada tes awal diperoleh nilai rata-rata sebelum diberikan tindakan sebesar 55,09 dan yang tuntas hanya 12 siswa dengan ketuntasan klasikal 36,36\%. Pada siklus I nilai rata-rata meningkat menjadi 66,91 dan siswa yang tuntas sebanyak 23 orang dengan ketuntasan klasikal 69,70\%. Siklus II nilai rata-rata siswa meningkat menjadi $77,88 \%$ dan yang tuntas sebanyak 31 siswa dengan ketuntasan klasikal 93,94\%. Maka dapat disimpulkan pembelajaran saintifik dapat meningkatkan hasil belajar siswa pada pembelajaran matematika di kelas V SD NEGERI NO. 107402 SAENTIS T.A 2015/2016.
\end{abstract}

Kata Kunci : Hasil Belajar, Matematika, Pendekatan Saintifik

\section{PENDAHULUAN}

Kemajuan dunia teknologi dan informasi dewasa ini tidak lepas kaitannya dengan dunia pendidikan. Pendidikan memegang peranan yang sangat penting, karena pendidikan memiliki kemampuan untuk mengembangkan kualitas manusia. Pembelajaran matematika di sekolah merupakan salah satu cara dalam meningkatkan kualitas manusia.

Matematika adalah salah satu mata pelajaran yang dapat mengembangkan kemampuan berpikir. Matematika merupakan pelajaran yang wajib diberikan di semua jenjang pendidikan mulai dari tingkat SD hingga tingkat perguruan tinggi.

Matematika sangat diperlukan untuk proses perhitungan dan proses berpikir dalam menyelesaikan berbagai permasalahan yang terjadi dalam kehidupan sehari-hari.

Secara khusus, pembelajaran matematika di SD bertujuan untuk menumbuhkan dan mengembangkan keterampilan berhitung sebagai latihan dalam kehidupan sehari-hari, mengembangkan kemampuan dasar matematika sebagai bekal belajar lebih lanjut, serta untuk meningkatkan kemampuan berpikir secara sistematis, kritis, logis dan kreatif.

Oleh karena pentingnya mata pelajaran matematika dilaksanakan dan diajarkan di SD dilihat dari tujuannya, maka pada proses pembelajaran seorang guru hendaknya dapat menciptakan kondisi dan situasi pembelajaran yang memungkinkan untuk meningkatkan keaktifan siswa dalam 
menemukan dan mencari penyelesaian terhadap suatu permasalahan serta mengembangkan kemampuan berpikir siswa dalam kegiatan pembelajaran sehingga tujuan pembelajaran yang telah ditentukan oleh guru dapat tercapai dan akan terlihat dari hasil belajar siswa. Namun pada kenyataannya membelajarkan matematika di SD masih sangat jauh dari harapan.

Berdasarkan pengamatan di kelas V SD Negeri 107402 saentis, masih banyak mengalami masalah dan hambatan dalam proses belajar mengajar matematika di antaranya, hasil belajar siswa pada mata pelajaran matematika masih rendah, siswa kurang antusias dalam mengikuti pembelajaran matematika dikarenakan siswa menganggap bahwa matematika adalah mata pelajaran yang sulit, pendekatan pembelajaran yang diterapkan oleh guru masih cenderung menggunakan pendekatan konsep, siswa cenderung hanya diberikan latihan-latihan soal oleh guru sehingga siswa kurang menyukai pembelajaran matematika, siswa cenderung kurang berani dalam menyelesaikan soal-soal yang diberikan guru di papan tulis, dan guru jarang menggunakan media pembelajaran pada saat mengajar.

Masalah-masalah yang dipaparkan di atas tentu perlu adanya solusi atas masalah tersebut. Untuk menyelesaikan masalah tersebut, maka guru harus mampu bersikap bijak dalam memilih dan menentukan pendekatan yang tepat khususnya pada mata pelajaran matematika. Pendekatan yang diharapkan adalah pendekatan yang mampu membuat siswa menjadi aktif dan antusias, mampu menyelesaikan soal-soal matematika, tidak mudah merasa bosan dan dapat menciptakan suasana belajar yang optimal.

Salah satu pendekatan yang mampu mengatasi masalah dalam pembelajaran matematika tersebut adalah dengan menggunakan pendekatan saintifik yang sesuai dengan kurikulum yang berlaku saat ini. Pembelajaran dengan pendekatan saintifik adalah proses pembelajaran yang dirancang sedemikian rupa untuk memberikan pemahaman kepada peserta didik dalam mengenal, memahami berbagai materi, menggunakan pendekatan ilmiah, bahwa informasi bisa berasal dari mana saja, kapan saja, tidak bergantung pada informasi searah dari guru.

\section{METODE PENELITIAN}

Jenis penelitian yang dilakukan dalam penelitian ini adalah Penelitian Tindakan Kelas (PTK) dengan menggunakan pendekatan saintifik. Penelitian ini dilaksanakan di SD Negeri 107402 Saentis. Subjek dalam penelitian ini adalah siswa kelas V SD Negeri 107402 Saentis T.A 2015/2016 sebanyak 33 orang siswa. Sedangkan Objek penelitian ini adalah tindakan untuk meningkatkan hasil belajar siswa pada mata pelajaran matematika materi pokok sifat-sifat bangun datar 
dengan menggunakan pendekatan saintifik dan dengan berbentuk siklus yang terdiri dari empat tahapan, yaitu: 1). Perencanaan, Pelaksanaan, 3). Pengamatan dan 4). Refleksi.

\section{HASIL DAN PEMBAHASAN}

Sebelum diadakan perlakuan pembelajaran dengan pendekatan saintifik terlebih dahulu diadakan tes awal untuk mengetahui tingkat penguasaan siswa. Adapun hasilnya adalah sebagai berikut:

Persentase Deskripsi Nilai Tes Awal siswa

\begin{tabular}{|c|c|c|c|c|c|c|}
\hline \multirow[b]{2}{*}{ Skor } & \multirow{2}{*}{$\begin{array}{c}\text { Tingkat } \\
\text { Hasil Belajar }\end{array}$} & \multirow{2}{*}{$\begin{array}{c}\text { No. } \\
\text { Responden }\end{array}$} & \multirow[b]{2}{*}{$\begin{array}{c}\text { Jumlah } \\
\text { Siswa }\end{array}$} & \multirow{2}{*}{$\begin{array}{c}\text { Persentase } \\
\text { Jumlah Siswa }\end{array}$} & \multicolumn{2}{|c|}{ Keterangan } \\
\hline & & & & & Tuntas & $\begin{array}{l}\text { Belum } \\
\text { Tuntas }\end{array}$ \\
\hline $\begin{array}{c}85- \\
100\end{array}$ & Baik Sekali & 10,28 & 2 siswa & $6,06 \%$ & Tuntas & - \\
\hline $75-84$ & Baik & $7,9,22$ & 3 siswa & $9,09 \%$ & Tuntas & - \\
\hline $60-74$ & Cukup & $\begin{array}{c}5,6,8,13,23 \\
24,29\end{array}$ & 7 siswa & $21,21 \%$ & Tuntas & - \\
\hline$<60$ & Kurang & $\begin{array}{c}1,2,3,4,11,1 \\
2,14,15,16,1 \\
7,18,19,20,2 \\
1,25,26,27,3 \\
0,31,32,33\end{array}$ & 21 siswa & $63,64 \%$ & - & $\begin{array}{l}\text { Belum } \\
\text { Tuntas }\end{array}$ \\
\hline \multicolumn{3}{|c|}{$\mathbf{N}$} & 33 siswa & $100 \%$ & 12 siswa & 21 siswa \\
\hline \multicolumn{3}{|c|}{ Jumlah nilai } & 1818 & & & \\
\hline \multicolumn{3}{|c|}{ Nilai rata-rata } & 55,09 & & & \\
\hline \multicolumn{5}{|c|}{ Persentase } & $36,36 \%$ & $63,64 \%$ \\
\hline
\end{tabular}

Berdasarkan data yang terdapat pada tabel di atas dapat dilihat gambaran siswa yang tuntas dan yang tidak tuntas mencapai nilai KKM yang telah ditentukan oleh sekolah pada mata pelajaran matematika, yaitu 60. Dari hasil dan ketentuan nilai KKM ditemukan sebanyak 12 orang siswa $(36,36 \%)$ yang tuntas dan 21 orang siswa $(63,64 \%)$ yang tidak tuntas. Rata-rata hasil belajar siswa adalah 55,09 dan tingkat ketuntasan klasikal mencapai $36,36 \%$. Hal tersebut menunjukkan bahwa tingkat ketuntasan belajar secara klasikal siswa masih di bawah $85 \%$.

\section{Siklus I \\ Perencanaan}

Adapun kegiatan yang dilakukan pada tahap perencanaan ini adalah: a). Menyusun Rencana Pelaksanaan Pembelajaran (RPP), b).Mempersiapkan materi yang akan diajarkan dan media bangun datar gambar persegi panjang, persegi dan segitiga melalui pendekatan saintifik pada pertemuan pertama dan pada pertemuan kedua media yang dipersiapkan yaitu gambar bangun 
datar trapesium, jajar genjang, lingkaran, layang-layang dan belah ketupat yang ditempel di karton, c). Membuat lembar observasi untuk mengamati situasi dan kondisi selama proses pembelajaran, dan Menyusun tes untuk mengetahui tingkat keberhasilan siswa selama tindakan penelitian dilakukan.

\section{Pelaksanaan pertemuan I}

Pada tahap awal proses pembelajaran pertemuan pertama sebelum memulai pembelajaran guru membuka pelajaran dengan mengucapkan salam kepada seluruh siswa dan siswa menjawab. Salah seorang siswa diminta untuk memimpin doa di depan kelas.

Setelah berdoa bersama, guru mengabsen siswa, memberikan apersepsi, memotivasi, menyampaikan materi yang akan dipelajari yaitu sifat-sifat bangun datar dengan menuliskannya di papan tulis dan dilanjutkan dengan penyampaian tujuan pembelajaran yang akan dicapai. Kegiatan inti, pada tahap ini siswa diajak untuk mengamati media gambar berbagai jenis bangun datar yang dibuat oleh guru. Kemudian siswa diminta untuk mengajukan pertanyaan tentang gambar-gambar bangun datar yang ada di papan tulis. Setelah melakukan tanya jawab, siswa diajak untuk memberikan pendapat tentang sifatsifat bangun datar berdasarkan pertanyaan yang diajukan oleh temannya.
Selanjutnya, guru membentuk siswa menjadi 5 kelompok, 3 kelompok terdiri dari masing-masing 6 orang, sedangkan 2 kelompok lagi terdiri dari masingmasing 7 orang. Setiap kelompok siswa ditugaskan untuk mengidentifikasi sifat-sifat bangun datar dari gambar yang dibagikan ke setiap kelompok. Guru mendatangi setiap kelompok untuk membimbing dan mengarahkan siswa dalam menyelesaikan tugas yang diberikan. Siswa bersama dengan teman sekelompoknya berdiskusi dan bekerja sama dalam mengumpulkan informasi dengan membaca buku tentang sifat-sifat bangun datar atau dari berbagai sumber lain yang diperlukan untuk menyelesaikan masalah. Selanjutnya setiap kelompok menarik kesimpulan dari berbagai sumber yang ada. dan menyampaikan hasil diskusinya di depan kelas. Guru dan siswa melakukan tanya jawab dan meminta kelompok lain memberikan tanggapan atau pertanyaan atas penyajian yang dilakukan oleh kelompok Pada akhir pembelajaran guru membimbing siswa dalam memberikan kesimpulan mengenai materi pelajaran yang telah dipelajari, memberikan pekerjaan rumah dan diakhiri dengan salam.

\section{Pertemuan kedua}

Tahap awal proses pembelajaran pertemuan kedua siklus I, guru membuka pelajaran dengan mengucapkan salam dan siswa 
menjawab salam dari guru, berdoa bersama yang dipimpin oleh salah seorang siswa dan dilanjutkan dengan mengabsen siswa satu per satu. Kemudian guru memberikan apersepsi, memotivasi, menyampaikan materi, menyampaikan tujuan pembelajaran yang akan dicapai selama pembelajaran berlangsung

Pada tahap inti ini, proses pembelajaran menggunakan pendekatan pembelajaran saintifik yang tidak jauh berbeda dengan pertemuan pertama yaitu siswa diminta untuk mengamati media gambar berbagai macam bangun datar yang telah dibuat oleh guru. Kemudian guru mengajak siswa untuk melakukan tanya jawab tentang gambar bangun datar. Setelah itu siswa diminta untuk memberikan pendapat tentang sifat-sifat bangun datar berdasarkan pertanyaan yang diajukan. Setelah itu guru membentuk siswa menjadi 5 kelompok diskusi seperti pada pertemuan I. Guru menugaskan setiap kelompok siswa untuk mengidentifikasi dan menuliskan sifat-sifat bangun datar jajar genjang, belah ketupat, layanglayang, dan trapesium. Setiap kelompok diberikan kesempatan untuk berdiskusi, mengumpulkan informasi, dan bertukar informasi dari berbagai sumber belajar yang berkaitan dengan materi. Setiap kelompok akan menganalisis informasi dari berbagai sumber. Apabila saat diskusi berlangsung ada kelompok yang mempertanyakan suatu hal yang tidak dimengerti maka guru akan memberikan bimbingan dan arahan. Setelah selesai berdiskusi perwakilan setiap kelompok diminta untuk menyampaikan hasil diskusinya di depan kelas. Bagi kelompok lain diberikan kesempatan untuk bertanya ataupun memberikan pertanyaan atas hasil diskusi yang disampaikan oleh kelompok yang presentase. Guru memberikan penghargaan kepada kelompok siswa yang aktif selama proses pembelajaran. Kemudian guru menunjuk beberapa orang siswa untuk menyampaikan kesimpulan dari materi yang telah dipelajari.

Pada akhir pembelajaran guru memberikan tes kepada siswa yang akan dikerjakan secara individual sebagai pencapaian hasil belajar melalui post tes. Guru mengawasi dan membimbing siswa dalam mengerjakan tes yang diberikan. Setelah selesai guru akan menutup pembelajaran dengan berdoa dan diakhiri dengan salam.

\section{Pengamatan}

Setelah

dilaksanakannya tindakan siklus I, pada kegiatan akhir guru memberikan soal tes kepada siswa yang bertujuan untuk mengetahui hasil belajar siswa dan sejauh mana pemahaman siswa terhadap materi pokok sifat-sifat bangun datar setelah diterapkan pendekatan saintifik dalam proses pembelajaran. Dengan jumlah soal sebanyak 10 butir soal dalam bentuk 
isian. Berdasarkan hasil pos tes siklus

I diperoleh nilai sebagai berikut:

Tabel Persentase Deskripsi Hasil Belajar Siswa Pada Siklus I

\begin{tabular}{|c|c|c|c|c|c|c|}
\hline \multirow[b]{2}{*}{ Skor } & \multirow{2}{*}{$\begin{array}{c}\text { Tingkat } \\
\text { Hasil } \\
\text { Belajar }\end{array}$} & \multirow{2}{*}{$\begin{array}{c}\text { No. } \\
\text { Responden }\end{array}$} & \multirow{2}{*}{$\begin{array}{c}\text { Jumlah } \\
\text { Siswa }\end{array}$} & \multirow{2}{*}{$\begin{array}{c}\text { Persentase } \\
\text { Jumlah Siswa }\end{array}$} & \multicolumn{2}{|c|}{ Keterangan } \\
\hline & & & & & Tuntas & $\begin{array}{l}\text { Belum } \\
\text { Tuntas }\end{array}$ \\
\hline $85-100$ & Baik Sekali & $10,22,28$ & 3 siswa & $9,09 \%$ & Tuntas & - \\
\hline $75-84$ & Baik & $6,7,9,23,24,26$ & 6 siswa & $18,19 \%$ & Tuntas & - \\
\hline $60-74$ & Cukup & $\begin{array}{c}1,4,5,8,12,13,1 \\
5,16,18,19,25 \\
29,32,33\end{array}$ & 14 siswa & $42,42 \%$ & Tuntas & - \\
\hline$<60$ & Kurang & $\begin{array}{c}2,3,11,14,17,2 \\
0,21,27,30,31\end{array}$ & 10 siswa & $30,30 \%$ & - & $\begin{array}{l}\text { Belum } \\
\text { Tuntas }\end{array}$ \\
\hline \multicolumn{3}{|c|}{$\mathbf{N}$} & 33 siswa & $100 \%$ & 23 siswa & 10 siswa \\
\hline \multicolumn{3}{|c|}{ Jumlah nilai } & 2208 & & & \\
\hline \multicolumn{3}{|c|}{ Nilai rata-rata } & 66,91 & & & \\
\hline \multicolumn{5}{|c|}{ Persentase } & $69,70 \%$ & $30,30 \%$ \\
\hline
\end{tabular}

Berdasarkan data dari tabel di atas, dapat diketahui bahwa nilai tes dari 33 orang siswa setelah diterapkan pendekatan saintifik dalam proses pembelajaran menunjukkan bahwa tingkat hasil belajar siswa yang tergolong kategori nilai baik sekali ada sebanyak 3 orang $(9,09 \%)$, siswa yang tergolong kategori nilai baik ada sebanyak 6 orang $(18,19 \%)$, siswa yang tergolong kategori nilai cukup ada sebanyak 14 orang $(42,42 \%)$, dan siswa yang tergolong kategori nilai kurang ada sebanyak 10 orang (30,30\%). Ini menunjukkan banyak nilai post tes siswa telah mengalami peningkatan dari hasil nilai pada tes awal. Dimana dari tes awal nilai rata-rata siswa adalah 55,09 dan pada post tes meningkat menjadi 66,91. Tingkat ketuntasannya dapat diperoleh dengan menggunakan rumus sebagai berikut :

$$
\mathrm{P}=\frac{\sum \text { siswa yang tuntas belajar }}{\sum \text { siswa }}
$$$$
\text { x } 100 \% \quad \text { (Aqib, } 2009: 41)
$$

- $\quad$ Tuntas $=\frac{12}{33}=36,36 \%$

- $\quad$ Tidak tuntas $=\frac{21}{33}=63,64 \%$

Dari dari hasil belajar yang diperoleh siswa, membuktikan bahwa hasil belajar siswa masih tergolong rendah dan ketuntasan belajar siswa secara klasikal belum tuntas atau belum $85 \%$.

Selanjutnya pada siklus I selama 2 kali pertemuan berlangsung, peneliti diobservasi oleh guru kelas V. Tujuan dari observasi ini adalah 
untuk menilai tingkat keberhasilan

Adapun hasil observasi guru dalam menerapkan pendekatan saintifik pada materi pokok sifat-sifat kemampuan guru (peneliti) bangun datar dalam proses menerapkan RPP dalam pembelajaran pembelajaran. dapat dilihat pada tabel berikut:

Tabel Hasil Observasi Kemampuan Guru Siklus I

\begin{tabular}{|c|c|c|c|c|c|c|c|c|c|c|c|}
\hline \multirow{3}{*}{ Aspek yang diamati } & \multirow{3}{*}{ Deskriptor } & \multicolumn{10}{|c|}{ Nilai Pengamatan } \\
\hline & & \multicolumn{5}{|c|}{ Pertemuan I } & \multicolumn{5}{|c|}{ Pertemuan II } \\
\hline & & 1 & 2 & 3 & 4 & skor & 1 & 2 & 3 & 4 & skor \\
\hline 1. Membuka pelajaran & $\begin{array}{ll}\text { - } & \text { Memberikan apersepsi } \\
\text { - } & \text { Memberikan motivasi } \\
\text { - } & \text { Menyampaikan tujuan } \\
& \text { pembelajaran }\end{array}$ & & & $\begin{array}{l}\sqrt{ } \\
\sqrt{ }\end{array}$ & $\sqrt{ }$ & 10 & & & $\begin{array}{l}\sqrt{ } \\
\sqrt{ }\end{array}$ & $\sqrt{ }$ & 10 \\
\hline $\begin{array}{l}\text { 2. Mengelola pembelaja } \\
\text { ran sesuai dengan } \\
\text { langkah pendekatan } \\
\text { saintifik } \\
\text { a. } \text { Mengamati }\end{array}$ & 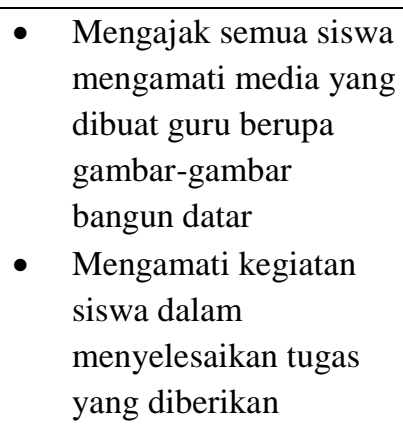 & & 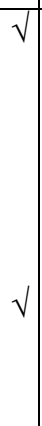 & & & 4 & & $\sqrt{ }$ & $\sqrt{ }$ & & 5 \\
\hline b. Menanya & $\begin{array}{ll} & \text { Menstimulus siswa } \\
\text { untuk mengajukan } \\
\text { pertanyaan }\end{array}$ & $\sqrt{1}$ & & & & 1 & & & $\sqrt{ }$ & & 3 \\
\hline $\begin{array}{l}\text { c. Mengumpulkan } \\
\text { informasi }\end{array}$ & $\begin{array}{l}\text { Menyediakan sumber- } \\
\text { sumber belajar bagi } \\
\text { siswa } \\
\text { Membimbing dan } \\
\text { mengarahkan siswa } \\
\text { dalam berdiskusi }\end{array}$ & & & $\sqrt{ }$ & $\sqrt{ }$ & 7 & & & & $\sqrt{ }$ & 8 \\
\hline $\begin{array}{l}\text { d. Menalar dan } \\
\text { mencoba }\end{array}$ & $\begin{array}{ll}- & \text { Memberikan } \\
\text { kesempatan bagi siswa } \\
\text { yang mau menjawab } \\
\text { pertanyaan } \\
\text { - Memberikan } \\
\text { kesempatan bagi siswa } \\
\text { yang ingin } \\
\text { memberikan tanggapan } \\
\text { atau pendapat }\end{array}$ & & & $\sqrt{1}$ & & 6 & & & $\sqrt{ }$ & $\sqrt{ }$ & 7 \\
\hline
\end{tabular}




\begin{tabular}{|c|c|c|c|c|c|c|c|}
\hline $\begin{array}{l}\text { e. Mengkomunikasi } \\
\text { kan }\end{array}$ & $\begin{array}{ll}\text { - } & \text { Meminta siswa } \\
\text { menyampaikan hasil } \\
\text { diskusi yang telah } \\
\text { dilakukan } \\
\text { - } & \text { Mau memberikan } \\
\text { respon atau tanggapan } \\
\text { kepada siswa } \\
\text { Mengembangkan } \\
\text { keberanian siswa } \\
\text { untuk mengemukakan } \\
\text { pendapat }\end{array}$ & & & 8 & & $\sqrt{ }$ & 10 \\
\hline 3. Menutup pelajaran & $\begin{array}{ll}\text { - } & \text { Memberikan } \\
\text { penghargaan kepada } \\
\text { siswa yang aktif } \\
\text { selama proses } \\
\text { pembelajaran } \\
\text { - } \\
\text { Menyimpulkan } \\
\text { pembelajaran } \\
\text { - Memberikan pekerjaan } \\
\text { rumah } \\
\end{array}$ & V & & 7 & $\sqrt{ }$ & $\sqrt{ }$ & 8 \\
\hline \multicolumn{2}{|c|}{ Jumlah } & & & 43 & & & 51 \\
\hline \multicolumn{2}{|c|}{ Rata-rata } & & & 2,68 & & & 3,18 \\
\hline
\end{tabular}

Berdasarkan data pada tabel di atas, dapat dilihat bahwa kemampuan mengajar guru selama proses tindakan siklus I pertemuan I tergolong baik dengan perolehan skor sebesar 2,68. Namun ada beberapa keterampilan yang belum terlaksana dengan efektif yakni pada aspek agar pada siklus II dapat terlaksana dengan baik. Sedangkan pada siklus I pertemuan II, dapat dilihat bahwa skor kemampuan yang diperoleh guru mengalami peningkatan yaitu dari 2,68 (pertemuan I) menjadi 3,18 (pertemuan II) yang tergolong baik. Namun ada beberapa keterampilan yang belum terlaksana dengan efektif yakni pada aspek mengamati khususnya mengamati kegiatan siswa dalam menstimulus siswa untuk mengajukan pertanyaan dan mengamati siswa dalam menyeleaikan tugas yang diberikan. Untuk itu, guru perlu memperbaiki kegiatan mengajarnya dengan memperhatikan berbagai indikator yang belum terlaksana tersebut: dalam menyelesaikan soal yang diberikan dan aspek menutup pelajaran dalam memberikan penghargaan kepada siswa yang aktif selama proses pembelajaran. Maka dari itu, guru perlu memperhatikan berbagai indikator yang kurang tercapai tersebut untuk diperbaiki pada kegiatan pembelajaran berikutnya. 


\section{Refleksi}

Berdasarkan data hasil belajar dan kemampuan guru di atas, ditemukan bahwa hanya sebagian kecil siswa yang mampu tepat waktu dalam menyelesaikan soal yang diberikan. dikarenakan kurang mengamati kegiatan siswa pada saat mengerjakan tugas, tidak banyak siswa yang berani mengajukan pertanyaan dikarenakan guru kurang menstimulus siswa untuk mengajukan pertanyaan, dan siswa kurang mampu mempresentasikan hasil diskusinya dengan baik yang dikarenakan guru kurang membimbing dan mengarahkan siswa dalam berdiskusi. Dengan demikian pada siklus II diharapkan guru dapat memperbaiki kelemahannya dan kekurangan dalam penerapan pendekatan saintifik berikutnya.

\section{Siklus II}

\section{Perencanaan}

Adapun rencana yang dipersiapkan adalah: a). Menyusun Rencana Pelaksanaan Pembelajaran (RPP), b). Mempersiapkan materi yang akan diajarkan dan media gambar bangun datar persegi panjang, persegi, dan segitiga pada pertemuan pertama dan pada pertemuan kedua mempersiapkan media gambar bangun datar jajar genjang, trapesium, layang-layang, belah ketupat, dan lingkaran melalui pendekatan saintifik, c). Membuat lembar observasi untuk mengamati situasi dan kondisi selama proses pembelajaran, d). Menyusun tes hasil belajar, dan e). Mengembangkan skenario pembelajaran dengan menggunakan pendekatan saintifik dalam kegiatan pembelajaran.

\section{Pelaksanaan Tindakan \\ Pertemuan pertama}

Pada siklus II pertemuan I, peneliti melaksanakan kegiatan pembelajaran berdasarkan pengembangan pelaksanaan pembelajaran yang telah disusun dengan menggunakan pendekatan saintifik. Kegiatan ini dilakukan untuk mengoptimalkan kegiatan yang belum terlaksana dengan baik pada pembelajaran siklus I.

Pada tahap awal, sebelum memulai pembelajaran guru membuka pelajaran dengan mengucapkan salam kepada seluruh siswa dan siswa menjawab salam dari guru, kemudian salah seorang siswa diminta memimpin doa. Setelah berdoa bersama, guru mengabsen siswa, memberikan apersepsi, memotivasi, menyampaikan materi yang akan dipelajari yaitu sifat-sifat bangun datar dengan menuliskannya di papan tulis dan dilanjutkan dengan penyampaian tujuan pembelajaran yang akan dicapai. Selanjutnya tahap inti, siswa diajak untuk mengamati media gambar berbagai jenis bangun datar yang dibuat oleh guru

Kemudian siswa distimulus untuk mengajukan pertanyaan terhadap gambar bangun datar yang diamati. Setelah itu siswa kembali diajak untuk memberikan pendapat tentang sifat-sifat bangun datar 
berdasarkan pertanyaan yang diajukan oleh temannya. Lalu guru guru membentuk siswa menjadi 5 kelompok, 3 kelompok terdiri dari masing-masing 6 orang, sedangkan 2 kelompok lagi terdiri dari masingmasing 7 orang untuk mengidentifikasi sifat-sifat dari bangun datar persegi, persegi panjang dan segitiga. Guru memberikan kesempatan kepada setiap kelompok untuk memberikan pertanyaan jika ada suatu hal yang tidak mengerti. Lalu guru akan mendatangi setiap kelompok untuk membimbing dan mengarahkan siswa dalam menyelesaikan tugas yang diberikan. Siswa bersama dengan teman sekelompoknya berdiskusi dan bekerja sama dalam mengumpulkan informasi dapat dengan membaca buku tentang sifat-sifat bangun datar atau dari berbagai sumber lain yang diperlukan untuk menyelesaikan masalah. Selanjutnya guru meminta setiap kelompok untuk menyampaikan hasil diskusinya. Guru dan siswa melakukan tanya jawab dan meminta kelompok lain memberikan pertanyaan atau tanggapan atas hasil diskusi yang disampaikan. Guru memberikan penghargaan kepada siswa yang aktif selama proses pembelajaran. Pada akhir pembelajaran guru membimbing siswa dalam memberikan kesimpulan mengenai materi pelajaran yang telah dipelajari, memberikan pekerjaan rumah dan diakhiri dengan salam.

\section{Pertemuan Kedua}

Guru membuka pelajaran dengan mengucapkan salam dan siswa menjawab salam dari guru, membaca doa dan dilanjutkan dengan mengabsen siswa satu per satu. Selanjutnya guru memberikan apersepsi dan motivasi, menyampaikan materi, dan menyampaikan tujuan pembelajaran yang akan dicapai selama pembelajaran berlangsung . Kemudian guru mengajak siswa untuk melakukan tanya jawab tentang gambar-gambar bangun datar yang telah diamati. Lalu siswa diajak untuk memberikan pendapat tentang sifatsifat bangun datar berdasarkan pertanyaan yang diajukan temannya. Setelah itu guru membentuk siswa menjadi 5 kelompok diskusi yang heterogen, dimana 3 kelompok terdiri dari masing-masing 6 orang siswa, sedangkan 2 kelompok lagi terdiri dari masing-masing 7 orang siswa. Guru menugaskan setiap kelompok siswa untuk mengidentifikasi dan menuliskan sifat-sifat bangun datar jajar genjang, belah ketupat, layanglayang, dan trapesium. Setiap kelompok diberikan kesempatan untuk berdiskusi, mengumpulkan informasi, dan bertukar informasi dari berbagai sumber belajar yang berkaitan dengan materi. Apabila saat diskusi berlangsung ada kelompok yang mempertanyakan suatu hal yang tidak dimengerti maka guru akan memberikan bimbingan dan arahan. Setelah selesai berdiskusi perwakilan setiap kelompok diminta untuk 
menyajikan Kemudian siswa dimotivasi untuk lebih gigih dan giat lagi untuk belajar matematika yang hasil diskusi yang disampaikan oleh kelompok yang presentase. Guru memberikan penghargaan kepada kelompok siswa yang aktif selama proses pembelajaran. Kemudian guru menunjuk beberapa orang siswa untuk memberikan kesimpulan dari materi yang telah dipelajari. Pada akhir pembelajaran guru memberikan tes kepada siswa yang akan dikerjakan secara individual sebagai pencapaian hasil belajar melalui post tes. Guru mengawasi dan membimbing siswa dalam mengerjakan tes yang diberikan. Setelah selesai guru akan menutup pembelajaran dengan berdoa dan diakhiri dengan salam. bermanfaat dalam kehidupan seharihari.

\section{Pengamatan}

Setelah dilaksanakannya tindakan siklus II, pada kegiatan akhir guru memberikan soal tes kepada siswa yang bertujuan untuk mengetahui hasil belajar siswa dan sejauh mana pemahaman siswa terhadap materi pokok sifat-sifat bangun datar setelah diterapkan pendekatan saintifik dalam proses pembelajaran. Dengan jumlah soal sebanyak 10 butir soal dalam bentuk isian kepada 33 orang siswa. Berdasarkan hasil post tes padaa siklus II diperoleh nilai post tes siswa berdasarkan ketuntasan siswa dapat dilihat pada tabel berikut:

Tabel Persentase Deskripsi Hasil Belajar Siswa Siklus II

\begin{tabular}{|c|c|c|c|c|c|c|}
\hline \multirow[b]{2}{*}{ Skor } & \multirow{2}{*}{$\begin{array}{c}\text { Tingkat } \\
\text { Hasil } \\
\text { Belajar }\end{array}$} & \multirow[b]{2}{*}{ No. Responden } & \multirow[b]{2}{*}{$\begin{array}{l}\text { Jumlah } \\
\text { Siswa }\end{array}$} & \multirow{2}{*}{$\begin{array}{c}\text { Persentase } \\
\text { Jumlah } \\
\text { Siswa }\end{array}$} & \multicolumn{2}{|c|}{ Keterangan } \\
\hline & & & & & Tuntas & $\begin{array}{l}\text { Belum } \\
\text { Tuntas }\end{array}$ \\
\hline $85-100$ & $\begin{array}{l}\text { Baik } \\
\text { Sekali }\end{array}$ & $\begin{array}{c}7,8,9,10,13,22,2 \\
4,28,29,32,33\end{array}$ & 11 siswa & $33,34 \%$ & Tuntas & - \\
\hline $75-84$ & Baik & $\begin{array}{c}1,4,5,6,12,15,18 \\
, 23,26,31\end{array}$ & 10 siswa & $30,30 \%$ & Tuntas & - \\
\hline $60-74$ & Cukup & $\begin{array}{c}3,11,14,16,17,1 \\
9,20,25,27,30\end{array}$ & 10 siswa & $30,30 \%$ & Tuntas & - \\
\hline$<60$ & Kurang & 2,21 & 2 siswa & $6,06 \%$ & - & $\begin{array}{l}\text { Belum } \\
\text { Tuntas }\end{array}$ \\
\hline \multicolumn{3}{|c|}{$\mathbf{N}$} & 33 siswa & $100 \%$ & 31 siswa & 2 siswa \\
\hline \multicolumn{3}{|c|}{ Jumlah nilai } & 2570 & & & \\
\hline \multicolumn{3}{|c|}{ Nilai rata-rata } & $\mathbf{7 7 , 8 8}$ & & & \\
\hline \multicolumn{5}{|c|}{ Persentase } & $93,94 \%$ & $6,06 \%$ \\
\hline
\end{tabular}


Berdasarkan data dari tabel di atas, dapat diketahui bahwa nilai post tes dari 33 orang siswa setelah diterapkan pendekatan saintifik dalam proses pembelajaran menunjukkan bahwa tingkat hasil belajar siswa yang tergolong kategori baik sekali ada sebanyak 11 orang $(33,34 \%)$, siswa yang tergolong kategori nilai baik ada sebanyak 10 orang $(30,30 \%)$, siswa yang tergolong kategori nilai cukup ada sebanyak 10 orang $(30,30 \%)$, dan siswa yang tergolong kategori nilai kurang ada sebanyak 2 orang $(6,06 \%)$. Nilai rata-rata 77,88 dan tingkat ketuntasan klasikal adalah 93,94\%. Pada siklus II juga dilaksanakan observasi oleh guru SD tersebut untuk melihat kemampuan guru mengajar dalam menerapkan RPP.

Adapun hasil observasi yang diperoleh berdasarkan indikator yang telah disusun sebelumnya, hasilnya sbb:

Tabel Hasil Observasi Kemampuan Guru Siklus II

\begin{tabular}{|c|c|c|c|c|c|c|c|c|c|c|c|}
\hline \multirow{3}{*}{$\begin{array}{l}\text { Aspek yang } \\
\text { diamati }\end{array}$} & \multirow{3}{*}{ Deskriptor } & \multicolumn{10}{|c|}{ Nilai Pengamatan } \\
\hline & & \multicolumn{5}{|c|}{ Pertemuan I } & \multicolumn{5}{|c|}{ Pertemuan II } \\
\hline & & 1 & 2 & 3 & 4 & Skor & 1 & 2 & 3 & 4 & skor \\
\hline $\begin{array}{l}\text { 1. Membuka } \\
\text { pelajaran }\end{array}$ & $\begin{array}{l}\text { *Memberikan apersepsi } \\
\text { *Memberikan motivasi } \\
\text { *Menyampaikan tujuan } \\
\text { pembelajaran }\end{array}$ & & & $\begin{array}{l}\sqrt{ } \\
\sqrt{ }\end{array}$ & $\sqrt{ }$ & 10 & & & $\sqrt{ }$ & $\begin{array}{l}\sqrt{ } \\
\sqrt{ }\end{array}$ & 11 \\
\hline $\begin{array}{l}\text { 2.Mengelola } \\
\text { pembelajaran } \\
\text { sesuai dengan } \\
\text { langkah } \\
\text { pendekatan } \\
\text { saintifik } \\
\text { a. Mengamati }\end{array}$ & $\begin{array}{l}\text { *Mengajak semua } \\
\text { siswa mengamati } \\
\text { media yang dibuat } \\
\text { guru berupa gambar- } \\
\text { gambar bangun datar } \\
\text { *Mengamati kegiatan } \\
\text { siswa dalam } \\
\text { menyelesaikan tugas } \\
\text { yang diberikan }\end{array}$ & & & & $\sqrt{ }$ & 8 & & & & $\sqrt{ }$ & 8 \\
\hline b. Menanya & $\begin{array}{l}\text { *Menstimulus siswa } \\
\text { untuk mengajukan } \\
\text { pertanyaan }\end{array}$ & & & $\sqrt{ }$ & & 3 & & & $\sqrt{ }$ & & 3 \\
\hline $\begin{array}{l}\text { c. Mengumpulkan } \\
\text { informasi }\end{array}$ & $\begin{array}{l}\text { - } \text { Menyediakan } \\
\text { sumber-sumber } \\
\text { belajar bagi siswa } \\
\text { - Membimbing dan } \\
\text { mengarahkan siswa } \\
\text { dalam berdiskusi }\end{array}$ & & & & $\sqrt{ }$ & 8 & & & & $\sqrt{ }$ & 8 \\
\hline
\end{tabular}




\begin{tabular}{|c|c|c|c|c|c|c|c|}
\hline $\begin{array}{l}\text { d. Menalar dan } \\
\text { mencoba }\end{array}$ & $\begin{array}{ll}\text { - Memberikan } & \\
\text { kesempatan } & \text { bagi } \\
\text { siswa yang } & \text { mau } \\
\text { menjawab } & \\
\text { pertanyaan } & \\
\text { *Memberikan } & \\
\text { kesempatan } & \text { bagi } \\
\text { siswa yang ingin } \\
\text { memberikan } & \\
\text { tanggapan } & \text { atau } \\
\text { pendapat } & \end{array}$ & $\sqrt{1}$ & $\sqrt{ }$ & 7 & & $\sqrt{ }$ & 8 \\
\hline $\begin{array}{l}\text { e.Mengkomunika } \\
\text {-sikan }\end{array}$ & $\begin{array}{l}\text { - Meminta siswa } \\
\text { menyampaikan hasil } \\
\text { diskusi yang telah } \\
\text { dilakukan } \\
\text { *Mau memberikan } \\
\text { respon atau } \\
\text { tanggapan kepada } \\
\text { siswa } \\
\text { - Mengembangkan } \\
\text { keberanian siswa } \\
\text { untuk } \\
\text { mengemukakan } \\
\text { pendapat }\end{array}$ & $\sqrt{ }$ & $\sqrt{ }$ & 11 & $\sqrt{ }$ & $\sqrt{ }$ & 11 \\
\hline $\begin{array}{l}\text { 3.Menutup } \\
\text { pelajaran }\end{array}$ & $\begin{array}{l}\text { - } \text { Memberikan } \\
\text { penghargaan kepada } \\
\text { siswa yang aktif } \\
\text { selama proses } \\
\text { pembelajaran } \\
\text { *.Menyimpulkan } \\
\text { pembelajaran } \\
\text { - Memberikan } \\
\text { pekerjaan rumah }\end{array}$ & $\sqrt{ }$ & $\sqrt{1}$ & 10 & & $\sqrt{ }$ & 12 \\
\hline \multicolumn{2}{|c|}{ Jumlah } & & & 57 & & & 61 \\
\hline \multicolumn{2}{|c|}{ Rata-rata } & & & 3,56 & & & 3,81 \\
\hline
\end{tabular}

Berdasarkan tabel di atas dapat terlihat bahwa adanya peningkatan kegiatan guru selama proses tindakan, dimana pada siklus II pertemuan I kegiatan guru tergolong sangat baik dengan perolehan skor sebesar 3,56. Sedangkan pada siklus II pertemuan
II terjadi peningkatan yang terlihat dari skor observasi yang diperoleh sebesar 3,81 .

\section{KESIMPULAN}

1. Hasil belajar siswa dapat meningkat dengan menggunakan pendekatan saintifik pada mata 
pelajaran matematika materi pokok sifat-sifat bangun datar.

2. Kemampuan guru menggunakan pendekatan saintifik pada siklus I tergolong baik dengan nilai ratarata pada pertemuan I sebesar 2,68 dan pertemuan II sebesar 3,18. Pada siklus II terjadi peningkatan kemampuan guru menjadi sangat baik dengan nilai rata-rata pada pertemuan I sebesar 3,56 dan pada pertemuan II sebesar 3,81.

\section{DAFTAR RUJUKAN}

Arikunto. 2010. Prosedur Penelitian Suatu Pendekatan Praktik. Jakarta: Rineka Cipta.

Aunurrahman. 2012. Belajar dan Pembelajaran. Pontianak:

Alfabeta.

Daryanto. 2014. Pendekatan Pembelajarn Saintifik

Kurikulum 2013

Yogyakarta: Gava Media.

Djamarah, Syaiful Bahri. 2011. Psikologi Belajar. Jakarta: Rineka Cipta.

Hendriana \& Soemarmo, 2014. Penilaian Pembelajaran Matematika. Bandung: Refika Aditama.

Istarani. 2015. Ensiklopedi Pendidikan. Medan: Media Persada.
Jihad dan Haris. 2013. Evaluasi Pembelajaran. Yogyakarta: Multi Presindo.

Kurinhasih \& Sani. 2014. Sukses Mengimplementasikan

Kurikulum 2013.

Yogyakarta: Kata Pena.

Mei. 2013. Implementasi Pendekatan Saintifik (Scientific Approach) dalam Pembelajaran Di Sekolah Dasar. Tersedia http://prosiding.upgrismg.ac. $\mathrm{id} /$ index.php/pgsd/pgsd/paper /view/321/273. Didownload pada tanggal 27 November 2015.

Purwanto. 2011. Evaluasi Hasil Belajar. Yogyakarta: Pustaka Belajar.

Sundayana. 2015. Media dan Alat Peraga dalam Pembelajaran Matematika. Bandung: Alfabeta.

Supardi. 2013. Sekolah efektif : Konsep Dasar dan Praktiknya. Jakarta: Rajagravindo Persada. 